\title{
Environmental Aspects of the Effect of Earthworm (Lumbricidae, Oligochaeta) Tropho-Metabolic Activity on the pH Buffering Capacity of Remediated Soil (Steppe Zone, Ukraine) ${ }^{1}$
}

\author{
Y. L. Kul'bachko ${ }^{a}$, O. O. Didur ${ }^{a}$, I. M. Loza ${ }^{a}$, O. E. Pakhomov ${ }^{a}$, and O. V. Bezrodnova ${ }^{b}$ \\ ${ }^{a}$ Oles' Honchar Dnipropetrovsk National University of Ukraine, pr. Gagarina 72, 49010 Dnipropetrovsk \\ ${ }^{b}$ Karazin Kharkiv National University Ukraine, pl. Svobody 4, 61022 Kharkiv \\ e-mail:didur@ua.fm \\ Received April 12, 2013
}

\begin{abstract}
Environmental aspects of tropho-metabolic activity of soil saprophages on the pH-buffering capacity of remediated soils in Ukraine was considered. Earthworm (Lumbricidae) casts have been proven experimentally to have a higher acid-base buffering capacity in comparison with that of the initial soil. Remediated soils enriched with earthworm casts become more resistant to negative anthropogenic effects. Thus, the activity of soil saprophages influences positively the environmental properties of remediated soils on forest remediation sites by increasing their buffer capacity.
\end{abstract}

Keywords: forest remediation, soil saprophages, tropho-metabolic activity, earthworm, acid-base buffering capacity

DOI: $10.1134 / \mathrm{S} 1062359015100088$

\section{INTRODUCTION}

Environmental protection, rational use of natural resources, and maintenance of ecological safety in human life are essential conditions for the sustainable economic and social development of Ukraine. Specifically, it is very important to solve the environmental challenges of Western Donbass as a major center of coal mining located within the southeastern part of Ukraine. The high-level industrial development of this region is associated with local subsidence, phreatic rise of saline groundwater, and dumping of mine wastes. As a result of coal mining, set-aside lands were developed. Technology-related local sites have been formed within such areas (Yeterevska, 1977; Zverkovsky, 1999), which are characterized by oligotrophication of the components of plant communities (Bezrodnova, 2000).

Disturbed areas formed during coal mining can be partially restored by remediation (Yeterevska, 1977; Uzbek et al., 2010). The initial stage of remediation is a technical stage, which is carried out by landscape alignment and soil coating. One of the main indicators of productivity of remediated land and acceptance for stocking by soil biota are considered to be the active soil acidity $(\mathrm{pH})$ and salinity parameters. In Western Donbass, toxic mine wastes that require remediation are represented by a mixture of argillites, siltstones, and black shale. The high density, amorphy, and high

\footnotetext{
${ }^{1}$ This article was translated by the authors.
}

salinity of waste water extracts determine the extremely low suitability of these substrates for the existence of biota (Volokh et al., 1996). Therefore, waste is usually covered by a remediation layer consisting of fine-grained nontoxic material. For this purpose, nonsaline loess-like loams and sometimes clay are used. The next stage of the remediation process is covering with a humus layer, for example muck mass (ordinary chernozem). Taking into account the lack of one, humus-free variations will be used (Volokh et al., 1996; Zverkovsky, 1999).

The final stage of restoration of disturbed lands is a biological stage of remediation. One of its varieties is forest remediation, oriented to creation of an ecologically balanced landscape, when the forest ecosystem is recreated (Travleyev et al., 1988; Tsvetkova, 1992). Among biota, the soil mesofauna plays a crucial role in development of the resistance mechanisms of forest plantations; in particular, representatives of the saprotrophic complex contribute greatly (earthworms, pot worms, millipedes, woodlice, etc.). These invertebrates contribute significantly to transformation of soil properties due to their tropho-metabolic activities. Such invertebrates are called "ecosystem engineers" and are able to influence the habitat and soil biota community through this activity; they can cause ecosystem succession (Tiunov, 2007; Eisenhauer, 2010; etc.). Study of habitat-transforming species ("ecosystem engineers") is currently gaining importance (Osipov, 2011). Assessments of the degree of their impact 


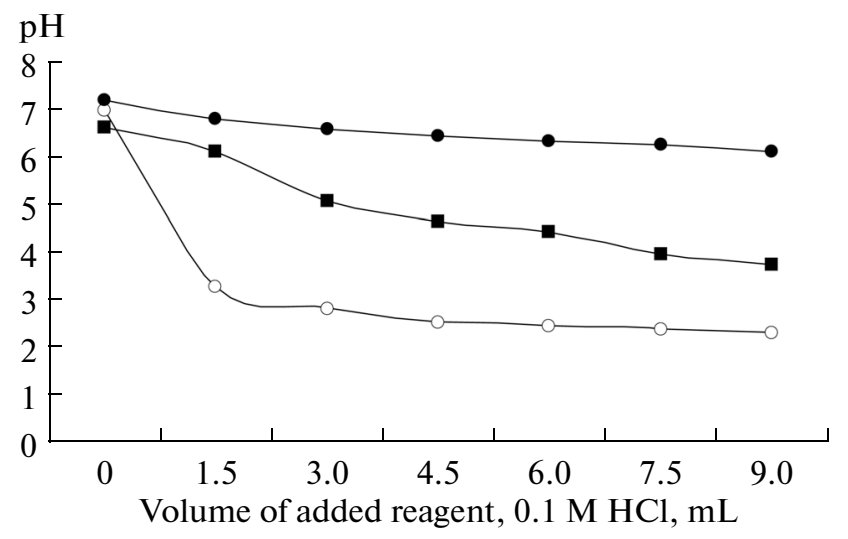

Fig. 1. The buffering curves (acid range) in the second variant of remediation (loess-like loam, earthworm casts) and sand: $\bigcirc$-sand, - - -loess-like loam topsoil, - - earthworm casts.

on the environment, particularly the effect of trophometabolic activity of earthworms on the remediated soil buffer capacity are of scientific and practical interest.

The soil buffering capacity is the process to maintain an unchanged chemical state upon exposure to a flow of chemical compounds. Often the buffering capacity is meant as the capacity of the soil to resist changes in the active soil acidity under the effect of various factors. It is known as acid-base buffering, or pH-buffering (Truskavetsky, 2003; Orlov, 2005). Most publications devoted to study of the buffering capacity of soil have an agricultural orientation (Truskavetsky, 2003; Hamkalo, 2004), or they are devoted to investigation of the buffering capacity in different genetic soil types, and it is not associated with soil-zoological components (Pozniak and Hamkalo, 2001; Hamkalo, 2004, 2005). Furthermore, the information about participation of soil saprophages in the formation and maintenance of buffer properties of remediated soil under forest plantations is absent. Therefore, the purpose of this article is to determine the soil and environmental efficiency of the contribution of earthworms to the acid-base (pH-buffering) ability of artificial soil at the sites of forest remediation.

\section{MATERIALS AND METHODS}

Field data were collected by investigators on a forest reclamation site in Western Donbass (Ukraine, Dnipropetrovsk region). Soil samples were collected at a depth of $0-10 \mathrm{~cm}$, and fresh excretions of the earthworm Aporrectodea caliginosa (Savigny, 1826) were collected at the surface on the remediation site in a plantation of Norway maple (Acer platanoides) (2nd and 3rd variants). The top layer of the second variant collected for analysis was represented by humus-free loess-like loam; and top layer of the third variant was represented by a humus filling layer of ordinary chernozem. Earthworm $A$. caliginosa is referred to endogeic soil worms. It is classified as a saprophage, secondary decomposer, nitrogen liberator, and humificator (Perel, 1979; Stryganova, 1980).

Determination of acid-base soil buffering and its neoformation (earthworm casts) is based on identification of $\mathrm{pH}$ changes due to addition of solutions of acids or alkalis. To determine the buffer capacity of earthworm casts and the soil, the authors used the Arrhenius method (Fiziko-khimicheskie metody..., 1980). According to the results of actual soil acidity measurements, a graph was constructed on which the abscissa axis indicated the number of milliliters of added acid (or alkali) solution and the ordinate axis indicated the corresponding $\mathrm{pH}$ values. The resulting curves of the graph allow us to estimate the soil buffering on the "buffering square" in the areas of acid and alkaline intervals, which is defined as the area between titration curves of soil (sample) and sand (reference standard) (Nadtochiy, 1993), and expressed in conditional square centimeters. The method of numerical integration was used to calculate the "buffering square." An example was solved by using the Simpson formula (Markushevich, 1979; Nadtochiy, 1993). Measurement of the active soil acidity $(\mathrm{pH})$ in the control and experimental samples was performed in three replications. The arithmetic mean, standard error, and significant difference of the mean were estimated (Lakin, 1990).

\section{RESULTS AND DISCUSSION}

For the second variant, changes in the $\mathrm{pH}$ values in the acid range are presented in Table 1 . Note that the loess-like loam has an initial conditionally neutral reaction, and earthworm casts have a neutral one. When even a small amount of acid solution $(3 \mathrm{~mL})$ was added, the loess-like loam reaction was changed from conventionally neutral (6.60) to acidic (5.07), while the earthworm casts with an initial neutral reaction (7.16) acquired a conventionally neutral one (6.55), keeping it even with the addition of a greater volume of acid.

When a small amount of alkali solution $(1.5 \mathrm{~mL})$ was added, the reaction of loess-like loam water solution remained conditionally neutral (6.70), and earthworm casts became slightly alkaline (7.43) from the initial reaction close to neutral (7.16). If a greater volume of alkaline solution $(6 \mathrm{~mL})$ was added, both loesslike loam and earthworm cast reactions became base ( 8.25 and 8.87 , respectively). The addition of the maximal volume of alkaline solution $(9 \mathrm{~mL})$ made an alkaline reaction in both samples.

In the acid range for the second variant of remediation (loess-like loam, earthworm casts) and sand, the titration curves of buffering are presented in Fig. 1. The buffering area of soil is located between the titration curve of sand and the titration curve of soil; the buffering area of casts is disposed between the titration curve of sand and the titration curve of casts. The dis- 
Table 1. Results of buffering measurement in acid and alkaline ranges, second variant of remediation (loess-like loam topsoil, earthworm casts) and sand (reference standard)

\begin{tabular}{c|c|c|c|c}
\hline \multirow{2}{*}{$\begin{array}{c}\text { Sample } \\
\text { no. }\end{array}$} & \multirow{2}{*}{$\begin{array}{c}\text { Volume of reagent } \\
\text { added, } \mathrm{mL}\end{array}$} & \multicolumn{3}{|c}{ Acidity, $\mathrm{pH}$} \\
\cline { 3 - 4 } & & sand & loess-like loam & earthworm casts \\
\hline & & \multicolumn{2}{|c}{ Acid range, reagent $0.1 \mathrm{M} \mathrm{HCl}$} \\
2 & 1.5 & $6.95 \pm 0.05$ & $6.60 \pm 0.05$ & $7.16 \pm 0.06$ \\
3 & 3.0 & $3.25 \pm 0.10$ & $6.09 \pm 0.07$ & $6.78 \pm 0.08$ \\
4 & 4.5 & $2.80 \pm 0.05$ & $5.07 \pm 0.09$ & $6.55 \pm 0.05$ \\
5 & 6.0 & $2.52 \pm 0.04$ & $4.64 \pm 0.07$ & $6.42 \pm 0.07$ \\
6 & 7.5 & $2.45 \pm 0.05$ & $4.43 \pm 0.08$ & $6.33 \pm 0.11$ \\
7 & 9.0 & $2.36 \pm 0.06$ & $3.93 \pm 0.11$ & $6.24 \pm 0.09$ \\
& & $2.29 \pm 0.04$ & $3.73 \pm 0.08$ & $6.10 \pm 0.08$ \\
1 & 0 & Alkaline range, reagent $0.1 \mathrm{M} \mathrm{NaOH}$ & $7.16 \pm 0.06$ \\
2 & 1.5 & $6.95 \pm 0.05$ & $6.60 \pm 0.05$ & $7.43 \pm 0.07$ \\
3 & 3.0 & $11.45 \pm 0.05$ & $6.78 \pm 0.08$ & $8.01 \pm 0.06$ \\
4 & 4.5 & $11.65 \pm 0.10$ & $7.20 \pm 0.10$ & $8.55 \pm 0.05$ \\
5 & 6.0 & $11.72 \pm 0.07$ & $7.72 \pm 0.07$ & $8.87 \pm 0.07$ \\
6 & 7.5 & $11.87 \pm 0.06$ & $8.25 \pm 0.10$ & $9.01 \pm 0.10$ \\
7 & 9.0 & $12.05 \pm 0.05$ & $8.75 \pm 0.05$ & $9.20 \pm 0.07$ \\
\hline
\end{tabular}

In what follows the arithmetic average and the standard error are presented.

position of the titration curves in such an interval testified that the buffering area of casts is significantly greater than the area of the corresponding loess-like loam buffering.

In Fig. 2 buffering curves in the alkaline range for the second variant of remediation (loess-like loam), earthworm casts, and sand were shown. The disposition of the titration curves testified that the size of the buffering area of casts is less than the buffering area for loess-like loam.

In Table 2, the values of buffering areas of loess-like loam and earthworm casts and their statistical evaluation are shown. The total area of the buffering capacity of casts was statistically significantly higher at $17.9 \%$ than the total area of the buffering capacity of loesslike loam. The area of the buffering capacity of casts in the acid range made a substantial contribution to the size of the total area.

Changes in the $\mathrm{pH}$ values for samples in the acid range (the third variant of remediation, fill layer of ordinary chernozem) were shown in Table 3. Ordinary chernozem has an initial conventionally neutral reaction, and casts have neutral one. After adding a small amount of acid solution $(1.5 \mathrm{~mL})$, the reaction of ordinary chernozem passed from a conventionally neutral reaction of the soil solution (6.82) to slightly acidic
(5.86), while the casts with a neutral reaction (7.16) acquired evident conventionally neutral reaction (6.33). When adding more acid solution ( 4.5 to $9 \mathrm{~mL}$ ), the reactions of the soil solution for ordinary chernozem and casts are qualitatively similar (acidic).

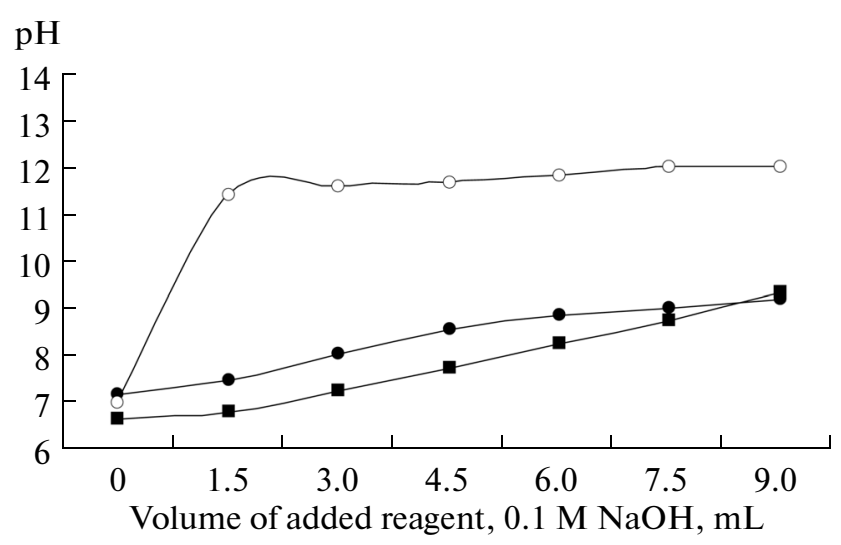

Fig. 2. The buffering curves (alkaline range) in the second variant of remediation (loess-like loam topsoil, earthworm casts) and sand: ○—sand, घ-loess-like loam, - — earthworm casts. 
Table 2. Evaluation of buffering capacity indexes for second variant of remediation (loess-like loam topsoil, earthworm casts)

\begin{tabular}{l|c|c}
\hline \multirow{2}{*}{\multicolumn{1}{c|}{ Range }} & \multicolumn{2}{c}{ Area of buffering, $\mathrm{cm}^{2}$} \\
\cline { 2 - 3 } & loess-like loam & earthworm casts \\
\hline Acid & $18.1 \pm 0.51$ & $32.5 \pm 0.52^{* *}$ \\
Alkaline & $33.8 \pm 0.43$ & $28.7 \pm 0.06^{*}$ \\
Acid-base, total & $51.9 \pm 0.60$ & $61.1 \pm 0.53^{* * *}$ \\
\hline
\end{tabular}

Significant difference of averages with significance level: $* \leq 0.05 ; * * \leq 0.01 ; * * * \leq 0.001$.

Table 3. Results of buffering measurement in the acid and alkaline ranges, third variant of remediation (ordinary chernozem topsoil, earthworm casts) and sand (reference standard)

\begin{tabular}{|c|c|c|c|c|}
\hline \multirow{2}{*}{ Sample no. } & \multirow{2}{*}{$\begin{array}{l}\text { Volume of added } \\
\text { reagent, } \mathrm{mL}\end{array}$} & \multicolumn{3}{|c|}{ Acidity, $\mathrm{pH}$} \\
\hline & & sand & ordinary chernozem & earthworm casts \\
\hline \multicolumn{5}{|c|}{ Acid range, reagent $0.1 \mathrm{M} \mathrm{HCl}$} \\
\hline 1 & 0 & $6.95 \pm 0.05$ & $6.82 \pm 0.12$ & $7.16 \pm 0.04$ \\
\hline 2 & 1.5 & $3.25 \pm 0.10$ & $5.86 \pm 0.11$ & $6.33 \pm 0.07$ \\
\hline 3 & 3.0 & $2.80 \pm 0.05$ & $5.37 \pm 0.10$ & $5.77 \pm 0.07$ \\
\hline 4 & 4.5 & $2.52 \pm 0.04$ & $4.86 \pm 0.09$ & $5.34 \pm 0.08$ \\
\hline 5 & 6.0 & $2.45 \pm 0.05$ & $4.38 \pm 0.08$ & $4.97 \pm 0.07$ \\
\hline 6 & 7.5 & $2.36 \pm 0.06$ & $4.12 \pm 0.12$ & $4.65 \pm 0.10$ \\
\hline 7 & 9.0 & $2.29 \pm 0.04$ & $4.00 \pm 0.10$ & $4.43 \pm 0.08$ \\
\hline \multicolumn{5}{|c|}{ Alkaline range, reagent $0.1 \mathrm{M} \mathrm{NaOH}$} \\
\hline 1 & 0 & $6.95 \pm 0.05$ & $6.82 \pm 0.12$ & $7.16 \pm 0.04$ \\
\hline 2 & 1.5 & $11.45 \pm 0.05$ & $7.68 \pm 0.08$ & $7.50 \pm 0.06$ \\
\hline 3 & 3.0 & $11.65 \pm 0.10$ & $8.67 \pm 0.12$ & $8.23 \pm 0.09$ \\
\hline 4 & 4.5 & $11.72 \pm 0.07$ & $9.42 \pm 0.09$ & $8.90 \pm 0.10$ \\
\hline 5 & 6.0 & $11.87 \pm 0.06$ & $9.94 \pm 0.08$ & $9.32 \pm 0.07$ \\
\hline 6 & 7.5 & $12.05 \pm 0.05$ & $10.31 \pm 0.05$ & $9.56 \pm 0.08$ \\
\hline 7 & 9.0 & $12.05 \pm 0.10$ & $10.46 \pm 0.13$ & $9.90 \pm 0.05$ \\
\hline
\end{tabular}

For the same variation of remediation, for the changes in $\mathrm{pH}$ for samples under the addition of a small amount of alkali solution $(1.5 \mathrm{~mL})$, the reaction of ordinary chernozem and casts was changed to slightly alkaline (7.68 and 7.50 , respectively) (see Table 3). Further, upon the addition of an alkaline solution to the ordinary chernozem and casts, an alkaline and strongly alkaline reaction developed. Thus, the reaction of the cast solution was less alkaline as compared with the corresponding reaction of soil samples (ordinary chernozem).

In Fig. 3, the curves of buffering in the acid range for the third variant of remediation (fill layer of ordinary chernozem), earthworm casts, and sand are shown. It will be recalled that the area of soil buffering is included between the titration curve of sand and the 


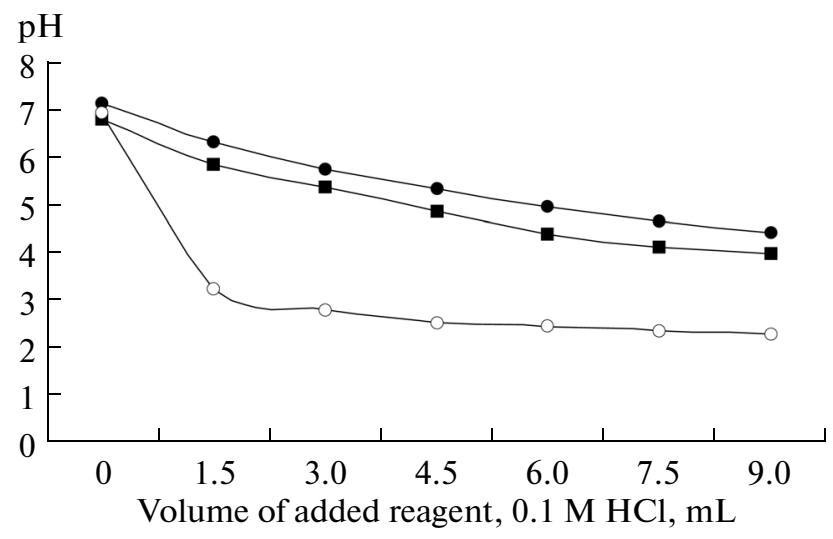

Fig. 3. The buffering curves (acid range) in the third variant of remediation (ordinary chernozem topsoil, earthworm casts) and sand: $\bigcirc$ - sand, $\mathbf{\square}$-ordinary chernozem topsoil, —-earthworm casts.

titration curve of soil; the area of buffering of earthworm casts is enclosed between the titration curve of sand and the titration curve of earthworm casts. In this range the disposition of the sample titration curves indicated that the buffering area of casts was more than the area of the soil buffer capacity.

In Fig. 4, the curves of buffering in the alkaline range for the third variant of remediation (fill layer of ordinary chernozem), earthworm casts, and sand are shown. The disposition of titration curves for samples (the buffering curve of earthworm casts is extended below the curve of soil buffering) suggested that the buffering area for casts is in excess of the area of the buffering capacity of ordinary chernozem.

In Table 4, the values of buffering areas of ordinary chernozem topsoil and earthworm casts in the third variant of remediation (Norway maple planting) were shown and their statistical evaluation was represented. The statistically significant difference for each interval of exposure was introduced. Thus, earthworm casts in this variant of remediation were characterized by a larger buffering area in both the acid and alkaline ranges as compared to the initial soil (fill layer of ordi-

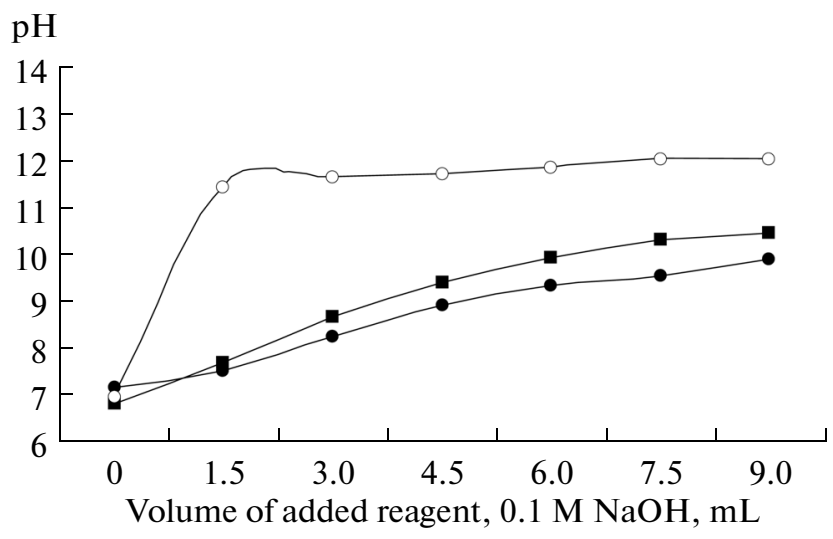

Fig. 4. The buffering curves (alkaline range) in the third variant of remediation (ordinary chernozem topsoil, earthworm casts) and sand: $\bigcirc$ - sand, a-ordinary chernozem topsoil, - - earthworm casts.

nary chernozem). It has been established that the total area of buffering capacity of earthworm casts (third variant of remediation) was significantly greater than the total area of the buffering capacity of soil by $20.8 \%$. The buffering area of earthworm casts in both the acid and alkaline ranges adds considerable support to the total area.

\section{CONCLUSIONS}

In the study of the environmental impact of tropho-metabolic activity of saprophages on remediated soil features, it was found that earthworm casts as products of earthworm excretory activity can change the buffer properties of remediated soil in sites of forestry remediation (Western Donbass, Ukraine). The results of an experiment conducted showed that the acid-base buffering capacity of earthworm casts was statistically significantly higher than the initial studied soil at 17.9 and $20.8 \%$ in different variants of forest remediation, which may contribute to a positive change in the soil ecological status in remediated sites. Thus, the efficiency of remediated soil recovery

Table 4. Evaluation of buffering capacity indexes for the third variant of remediation (ordinary chernozem topsoil, earthworm casts)

\begin{tabular}{l|c|c}
\hline \multirow{2}{*}{ Range of external influence } & \multicolumn{2}{|c}{ Area of buffering, $\mathrm{cm}^{2}$} \\
\cline { 2 - 3 } & ordinary chernozem & earthworm casts \\
\hline Acid & $18.9 \pm 0.38$ & $23.3 \pm 0.52^{*}$ \\
Alkaline & $21.6 \pm 0.54$ & $25.7 \pm 0.45^{*}$ \\
Acid-base, total & $40.5 \pm 0.57$ & $49.0 \pm 0.62^{* * *}$ \\
\hline
\end{tabular}

Significant difference of averages with significance level: * $\leq 0.07 ; * \leq 0.05 ; * * * \leq 0.001$. 
increased after enrichment in earthworm casts, and the quality of remediated soil was improved.

\section{REFERENCES}

Bezrodnova, O.V., Anthropogenic transformation of herbaceous vegetation in the Samara River valley within the borders of Western Donbass, Extended Absract of Cand. Sci. (Biol.) Dissertation, Dnepropetrovsk, 2000.

Eisenhauer, N., The action of an animal ecosystem engineer: identification of the main mechanisms of earthworm impacts on soil microarthropods, Pedobiologia, 2010, vol. 53, no. 6, pp. 343-352.

Yeterevska, L.V., Rekl'tivatsiya zemel'(Land Recultivation), Kiev: Urozhai, 1977.

Fiziko-khimicheskie metody issledovaniya pochv (Physicochemical Methods of Soil Analysis), Zyrin, N.G. and Orlov, D.S., Eds., Moscow: Mosk. Gos. Univ., 1980.

Hamkalo, Z., Differential acid-base buffering of soil as yardstick of ecological efficiency of an organic component of fertilizings of agrophytocenosises, Gruntoznavstvo, 2004, vol. 5, nos. 3-4, pp. 43-46.

Hamkalo, Z.G., Role of organic fertilizers in optimization of acid-base buffer properties of gray forest soils in the western Ukrainian forest-steppe, Agrokhim. Gruntozn., 2005, no. 66, pp. 53-58.

Lakin, G.F., Biometriya (Biometrics), Moscow: Vysshaya Shkola, 1990.

Markushevich, A.I., Ploshchadi i logarifmy (Areas and Logarithms), Moscow: Nauka, 1979.

Nadtochiy, P.P., Assessment of soil acid-base buffer capacity, Pochvovedenie, 1993, no. 4, pp. 34-39.

Orlov, D.S., Sadovnikova, L.K., and Sukhanova, L.I., Khimiya pochv (Soil Chemistry), Moscow: Vysshaya Shkola, 2005.

Osipov, V.V., Effect of environment-forming activities of European beavers (Castor fiber L.) on fish associations of small rivers in the Privolzhskaya Lesostep' Nature Reserve, Povolzh. Ekol. Zh., 2011, no. 3, pp. 378-385.

Perel, T.S., Rasprostranenie $i$ zakonomernosti rasprostraneniya dozhdevykh chervei fauny SSSR (The Pattern and
Trends of the Distribution of Earthworms in the Fauna of the Soviet Union), Moscow: Nauka, 1979.

Pozniak, S.P. and Hamkalo, M.Z., The acid-base buffer capacity of brown metamorphic soils in the Ukrainian Carpathians, Euras. Soil. Sci., 2001, vol. 34, no. 6, pp. 584592.

Stryganova, B.R., Pitanie pochvennykh saprofagov (The Feeding of Soil Saprophages), Moscow: Nauka, 1980.

Tiunov, A.V., Metabiosis in the soil system: effect of earthworms on the structure and functioning of soil biota, Extended Absract of Doctoral (Biol.) Dissertation, Moscow: Severtsov Inst. Ecol. Evol., Russ. Acad. Sci., 2007.

Travleyev, A.P., Ovchinnikov, V.A., Zverkovsky, V.N., Tsvetkova, N.N., and Lyndya, A.G., Biogeotsenoticheskii pokrov Zapadnogo Donbassa, ego tekhnogennaya dinamika i optimizatsiya: uchebnoe posobie (The Biogeocenotic Cover of the Western Donbass: Technogenic Dynamics and Optimizaton. A Textbook), Dnepropetrovsk: Dnepropetrovsk. Gos. Univ., 1988.

Truskavetsky, R.S., Buferna sdatnist' gruntiv ta ikh osnovni funktsii (The Buffer Capacity of Soils and Their Basic Functions), Kharkiv: Nove Slovo, 2003.

Tsvetkova, N.N., Osobennosti migratsii organo-mineral'nykh veshchestv i mikroelementov $v$ lesnykh biogeotsenozakh stepnoi Ukrainy (Specific Features of Migration of Organomineral Compounds and Trace Elements in Forest Biogeocenoses of Ukrainian Steppes), Dnepropetrovsk: Dnepropetrovsk. Gos. Univ., 1992.

Uzbek, I.Kh., Kobets, A.S., Volokh, P.V., Dyrda, V.I., and Demidov, A.A., Rekul'tivatsiya narushennykh zemel' kak ustoichivoe razvitie slozhnykh tekhnoekosistem (Remediation of Disturbed Lands as a Factor of Sustainable Development of Complex Technoecosystems), Uzbek, I.Kh., Ed., Dnepropetrovsk: Porogi, 2010.

Volokh, P.V., Kulinich, V.V., Masyuk, N.T., Novikov, V.P., Novikova, A.I., Obernyak, I.N., and Fenenko, V.I., Vremennye metodicheskie rekomendatsii po otsenke rekul'tivirovannykh zemel' (Temporary Methodological Guidelines for Recultivated Land Evaluation), Dnepropetrovsk, 1996.

Zverkovsky, V.N., Biogeocenological rationale for forest remediation of lands disturbed by coal mining in the steppe zone of Ukraine, Doctoral (Biol.) Dissertation, Dnepropetrovsk, 1999. 